УдК 615.212.032-06:616.89-008.441.33-084

DOI 10.11603/2411-1597.2019.4.10829

\title{
ПРИНЦИПИ ПРОФІЛАКТИЧНОЇ РОБОТИ СЕРЕД СПОЖИВАЧІВ ІН'ЄКЦІЙНИХ НАРКОТИКІВ
}

\author{
I. В. Явкіна \\ Миколаӥвська міська лікарня \\ Тернопільський національний медичний університет \\ імені І. Я. Горбачевського МОЗ Украӥни
}

У статті охарактеризовано основні принципи організації профілактичної роботи серед споживачів ін'єкційних наркотиків.

\section{PRINCIPLES OF PREVENTIVE WORK AMONG INJECTIVE DRUGS USERS}

\author{
I. V. Yavkina \\ Mykolaiv City Hospital \\ I. Horbachevsky Ternopil National Medical University
}

The article describes the basic principles of organisation of preventive work among injective drugs users.

Вступ. Всесвітньою організацією охорони здоров'я спільно з іншими агенціями ООН було розроблено важливі принципи профілактичних заходів, які узагальнили позитивний досвід багатьох країн у напрямку організації профілактичної роботи серед споживачів ін'єкційних наркотиків. Науковці та медики стверджують, що максимальний ефект досягається, коли ці принципи застосовують комплексно. До основних принципів профілактичної роботи серед споживачів ін'єкційних наркотиків (CIH) належать такі:

- інформаційна робота й освіта споживачів ін'єкційних наркотиків;

- забезпечення доступності для $\mathrm{CIH}$ соціальних служб і служб охорони здоров'я;

- безпосередня робота в середовищі СІH (вулична робота, залучення до програми волонтерів із представників споживачів ін'єкційних наркотиків);

- надання споживачам ін'єкційних наркотиків засобів безпеки - стерильного ін'єкційного інструмента, матеріалів для дезінфекції, презервативів для захищеного сексу;

- створення можливості для споживачів ін'єкційних наркотиків отримати замісну терапію.

Правильна реалізація та комплекс поєднання цих принципів створюють необхідну основу для ефективного здійснення програми в цілому.

() І. В. Явкіна, 2019
Основна частина. Проблему організації профілактичної роботи серед споживачів ін'єкційних наркотиків розглядають на державному рівні (Указ Президента України «Про невідкладні заходи щодо запобігання поширенню ВІЛ-інфекції/СНІДу» [5]); проведення аналізу економічної ефективності проектів із профілактики ВІЛ-інфекції/СНІДу в Україні [1]; встановлення можливостей розвитку в Україні програм профілактики ВІЛ-інфекції в середовищі споживачів ін'єкційних наркотиків [2]. Науковці визначають основні напрямки роботи програм «Зменшення шкоди серед осіб, які вживають наркотики ін'єкційним шляхом» [3] та «12 кроків» [6]; аргументують доцільність організації діяльності консультативних пунктів «Довіра» центрами соціальних служб для молоді [4] та ін.

Розглянемо ґрунтовніше основні принципи організації профілактичної роботи серед споживачів ін'єкційних наркотиків.

Принцип 1. Інформаційна робота й освіта споживачів ін'єкційних наркотиків.

Міжнародна практика показала, що друкована інформаційна продукція сама по собі $є$ малоефективною у запобіганні ВІЛ-інфекції серед споживачів ін'єкційних наркотиків. Вкрай необхідним є особистий контакт. Однак інформаційну роботу мають проводити не лише серед споживачів ін'єкційних наркотиків, але й серед інших верств населення, у першу чергу 
- серед підлітків, молоді та їхніх батьків, медичних працівників, представників правоохоронних органів, представників засобів масової інформації.

Профілактична інформаційна робота серед підлітків, молоді та їхніх батьків має на меті попередити немедичне вживання хімічних речовин, зловживання лікарськими препаратами, що мають наркогенну дію. Це відбувається шляхом ознайомлення молоді зі шкідливим впливом на організм наркотичних речовин, пропаганди альтернативних засобів зняття стресового напруження, усунення агресивних і депресивних психоемоційних станів, надання інформації про можливість для підлітків, молоді та їхніх батьків отримати кваліфіковану психологічну, медичну, правову та соціальну допомогу.

Принцип 2. Забезпечення доступності для споживачів ін'єкційних наркотиків соціальних служб і служб охорони здоров'я.

Успіх профілактики ВІЛ-інфекції серед населення, а особливо споживачів ін'єкційних наркотиків, залежить від кількості охоплених нею в регіоні активних споживачів, від належної довіри споживачів ін'єкційних наркотиків до медичних і соціальних працівників, тривалості контакту з ними, від того, чи є допомога комплексною. Така програма значною мірою передбачає реалізацію цього принципу через доступність для споживачів ін'єкційних наркотиків соціальних служб і служб охорони здоров'я. Фахівці повинні використовувати всі можливі засоби для створення умов, що сприятимуть тривалій роботі, наближенню соціальних і медичних служб до споживачів ін'єкційних наркотиків. Для цього необхідно визначити ті місця й установи в регіоні, де концентруються споживачі ін'єкційних наркотиків: місця традиційних зустрічей і спілкування, інфекційні та наркологічні клініки, тубдиспансери. У медичних закладах, до яких споживачі ін'єкційних наркотиків ставляться позитивно, при центрах соціальних служб для сім'ї, дітей та молоді, громадських організаціях доцільно створювати служби профілактики ВІЛ, соціальні та медичні служби для роботи з ін'єкційними споживачами наркотиків та членами їхніх сімей «Довіра» [4].

З урахуванням основних місць і часу перебування споживачів ін'єкційних наркотиків медпрацівникам разом із соціальними службами необхідно планувати і здійснювати польові маршрути, маршрути мобільних пунктів, щоб безпосередньо працювати в середовищі споживачів ін'єкційних наркотиків, поглиблювати подальшу профілактичну роботу за програмою. Доцільність і ефективність розташування стаціонарних соціальних служб та маршрутів вуличної роботи необхідно визначити за допомогою проведення фокус-груп із представниками споживачів ін'єкційних наркотиків регіону.

Принцип 3. Безпосередня робота у середовищі споживачів ін'єкційних наркотиків - вулична робота, залучення до програми волонтерів із представників споживачів ін'єкційних наркотиків.

Найефективнішою за результатом $\epsilon$ безпосередня робота із споживачами ін'єкційних наркотиків. Вона потребує систематичності, толерантного ставлення до них, розуміння того, що представники споживачів ін'єкційних наркотиків не можуть водночас змінити власну поведінку на більш безпечну. Наполягання на термінових результатах не $є$ реалістичним і може призвести до втрати контакту з користувачами програми.

На небезпечну поведінку потрібно впливати при безпосередніх контактах під час обміну шприців, видачі дезінфекційних засобів, інформаційних матеріалів. При цьому важливо показати і навчити споживачів ін'єкційних наркотиків, як продезінфікувати інструментарій, правильно скористатися презервативом, нагадати, куди і до кого можна звернутися при абсцесі або інфекційному захворюванні, де можна пройти тестування та консультування щодо ВІЛ-інфекції.

Особливу увагу працівники програми повинні звернути на ту обставину, що вони не забезпечать споживачів ін'єкційних наркотиків новими шприцами, а здійснюють обмін брудних шприців, потенційно інфікованих ВІЛ та іншими інфекціями, на стерильні.

Правильне дотримання цього принципу забезпечує тривалий і міцний контакт працівників програми і споживачів ін'єкційних наркотиків, їхніх батьків і рідних, дає змогу консультувати та інформувати споживачів ін'єкційних наркотиків про ризикову і безпечну поведінку в умовах ВІЛ-епідемії, сприяє формуванню міцних зв'язків з ними для подальшої їх інтеграції у суспільство.

Принцип 4. Надання споживачам ін'єкційних наркотиків засобів безпеки - стерильного ін'єкційного інструмента, матеріалів для дезінфекції, презервативів для захищеного сексу.

Обмін використаних шприців на стерильні, навчання споживачів ін'єкційних наркотиків дезінфекційної обробки посуду, інвентарю, навичок захищеного сексу тощо є вкрай необхідними умовами для запобігання 
поширенню ВІЛ-інфекції не тільки в середовищі споживачів наркотиків, а і серед населення регіону загалом. Щоб це стало доступним, необхідно навчати СІн і залучати їх до програми, щоб набуті вміння і навички вони змогли застосувати у своїй практиці, коли вживають наркотики та ведуть статеве життя.

Одне з головних завдань програми «Профілактика ВІЛ-інфекції/СНІДу серед молодих людей, які вживають наркотики ін'єкційним шляхом» - навчання споживачів ін'єкційних наркотиків безпечної поведінки щодо ураження на ВІЛ-інфекцію. Головне завдання медичних працівників, які здійснюють таку програму, не тільки надати користувачам необхідні засоби захисту, але й навчати людей, які належать до групи $\mathrm{CIH}$, правильно і постійно їх застосовувати. Для цього необхідно:

- забезпечити безперервну роботу програми потрібною кількістю шприців, дезінфекційних матеріалів, презервативів;

- навчити працівників програми - спеціалістів центру соціальних служб для сім'ї, дітей та молоді, залучених фахівців-медиків, волонтерів, педагогів умінь проведення дезінфекції посуду, ін'єкційного інструментарію та інших засобів для приготування, фасування та введення ін'єкційних наркотиків;

- навчити техніки безпеки при обміні, зборі та зберіганні використаних шприців;

- роз'яснити споживачам ін'єкційних наркотиків зміст та сутність програми, заохотити їх до зменшення (усунення) практики вживання наркотиків, ризику інфікування ВІЛ, довести до усвідомлення ними того факту, що саме по собі використання стерильного шприца ще не убезпечує повною мірою від інфікування ВІЛ, оскільки інфікованим наркотик може бути вже при виготовленні;

- привернути увагу споживачів ін'єкційних наркотиків на можливість зараження ВІЛ-інфекцією під час незахищеного статевого контакту і необхідності зміни ризикованого поводження на безпечне;

- заохотити схильних до відмови від вживання наркотиків споживачів ін'єкційних наркотиків до лікування та реабілітації;

- забезпечити систематичну та повну утилізацію голок і шприців, що були використані клієнтами програми.
Принцип 5. Створення можливості для споживачів ін'єкційних наркотиків отримувати замісну терапію.

Програми замісної терапії впроваджують в Україні експериментально і використовують в умовах медичного нагляду за особами, які вживають опіоїди і залежні від них. Це заміщення нелегального ін'єкційного наркотику легальним, який приймають внутрішньо (перорально), а не ін'єкційно. Така терапія - один із компонентів служб медичної допомоги, що доповнюється психологічною і соціальною підтримкою. Призначення споживачам ін'єкційних наркотиків замісної терапії в умовах медичного нагляду дозволяє знизити ризик передачі ВІЛ-інфекції, передозування, кримінальної поведінки, ін'єкційного вживання наркотичних речовин, поліпшує соматичне і психічне здоров'я цих осіб, спонукає споживачів наркотиків звертатися до лікувально-терапевтичних закладів.

В Україні досвід впровадження замісної терапії має Київська міська наркологічна клінічна лікарня «Соціотерапія», Черкаський обласний наркологічний диспансер, деякі інші наркологічні служби. При відповідних умовах цей досвід можна використати і в інших регіонах.

Висновки. Спеціальні дослідження показують, що уразливість споживачів ін'єкційних наркотиків ВІЛ-інфекцією зумовлена ризикованою поведінкою, що пов'язана передусім використанням ін'єкційних інструментів. Сама ризикована поведінка, з одного боку, робить споживачів ін'єкційних наркотиків дуже вразливими до зараження інфекційними хворобами, а з іншого - визначає ризик поширення ВІЛ-інфекції від споживачів ін'єкційних наркотиків до інших груп суспільства. Крім ризиків для здоров'я, вживання наркотиків також може стати причиною соціального виключення, ізоляції, дискримінації. Організація профілактики ВІЛ-інфекції/СНІДу серед молодих людей, які вживають наркотики ін'єкційним шляхом, має важливі принципи, які розроблені Всесвітньою організацією охорони здоров'я, та широко застосовуються країнами, зацікавленими в ефективній боротьбі з поширенням ВІЛ-інфекції серед споживачів ін'єкційних наркотиків та населення в цілому. Максимальний ефект досягається за умови, коли ці принципи застосовують комплексно. 


\section{СПИСОК ЛІТЕРАТУРИ}

1. Аналіз економічної ефективності проектів з профілактики ВІЛ/СНІД в Україні. - К. : Український інститут соціальних досліджень, 2013. - 99 с.

2. Балакірєва О. М. Оцінка можливостей розвитку в Україні програм профілактики ВІЛ в середовищі споживачів ін'єкційних наркотиків / О. М. Балакірєва, М. Ю. Варбан, О. О. Яременко. - К. : Центр «Соціальний моніторинг», 2013. - 257 с.

3. Основні напрямки роботи, навички та уміння волонтера програми «Зменшення шкоди серед осіб, які вживають наркотики ін'єкційним шляхом» / за ред. Б. П. Лазоренка, І. М. Пінчук. - К. : Центр соціальних експертиз, 2015. - 140 с.
4. Організація діяльності консультативних пунктів «Довіра» центрами соціальних служб для молоді : методичний посібник / за ред. Б. П. Лазоренка, І. М. Пінчук. - К., 2016. - 138 с.

5. Про невідкладні заходи щодо запобігання поширенню ВІЛ-інфекції/СНІДу : Указ Президента України від 01.11.2000 p. № 1182.

6. Щербина Л. Ф. Експериментальне дослідження мотиваційно-смислової сфери осіб, залежних від наркотичних речовин, в умовах реабілітації на основі програми «12 кроків» / Л. Ф. Щербина // Практична психологія та соціальна робота. - 2013. - № 6-7. - С. 69-76.

Отримано 04.11.19 